\title{
Perbandingan Aktivitas Pemodelan dengan Pendekatan Analitik dan Pendekatan Konstruktif untuk Siswa SMA di Yogyakarta
}

\author{
Anggi Catur Saputri ${ }^{1}$ danFlorentina Nova Andriani ${ }^{2}$ \\ Mahasiswa S1 Pendidikan Matematika FKIP Universitas Sanata Dharma \\ email: anggicasaputri@gmail.com ${ }^{1}$, andrianiflorentina@gmail.com ${ }^{2}$
}

\begin{abstract}
Abstrak
Penelitian ini bertujuan untuk membandingkan antara pendekatan analitik dan konstruktif dalam aktivitas pemodelan suatu masalah matematika serta melihat pendekatan mana yang dapat membuat siswa berpikir logis, kritis dan sistematis. Penelitian ini, dilakukan dengan mengambil 7 siswa sebagai sampel random dari populasi siswa kelas XI SMA di Yogyakarta kemudian membagi menjadi dua kelompok. Kelompok pertama menyelesaikan masalah yang diberikan dengan pendekatan analitik sedangkan kelompok lain menggunakan pendekatan konstruktif. Data hasil penelitian ini berupa deskripsi proses penyelesaian masalah matematika dan hasil pekerjaan yang dilakukan oleh kedua kelompok. Hasil dari penelitian ini, siswa yang menggunakan pendekatan analitik terlihat logis, sistematis namun kurang kritis karena terlalu banyak bertanya dan menunggu arahan. Siswa tidak memeriksa kembali hasil pekerjaannya. Sedangkan, siswa dengan pendekatan konstruktif cukup logis, kritis namun terkadang kurang sistematis. Siswa mengerjakan berdasarkan pemahamannya terhadap masalah yang diberikan. Setelah menyelesaikan soal siswa memeriksa kembali hasil pekerjaannya.
\end{abstract}

Kata-kata kunci : pemodelan matematis, pendekatan analitis, pendekatan konstruktif.

\section{PENDAHULUAN}

Matematika merupakan salah satu mata pelajaran wajib yang ada pada setiap jenjang pendidikan. Alur berpikir yang logis, kritis, dan sistematis merupakan beberapa hal yang dapat dikembangkan dalam menyelesaikan suatu masalah matematika. Alur berpikir yang digunakan siswa dapat terlihat dalam prosesnya menyelesaikan masalah matematika. Penyelesaian masalah matematika tersebut membuat kemampuan memodelkan menjadi hal yang tidak kalah penting. Pemodelan Matematis merupakan salah satu tahap dari pemecahan masalah matematika. Kemampuan memodelkan suatu masalah matematika tersebut dapat dilatih atau diasah melalui pendekatan-pendekatan tertentu.

Peneliti ingin membantu mengembangkan kemampuan siswa dalam menyelesaikan masalah matematika yang secara tidak langsung dapat melatih alur berpikir logis, kritis dan sistematis. Untuk mengembangkan kemampuan ini, peneliti perlu menggunakan pendekatan yang tepat dan efektif.

Berdasarkan latar belakang diatas, peneliti membandingkan antara pendekatan analitik dan konstruktif dalam aktivitas pemodelan suatu masalah matematika dan melihat pendekatan mana yang dapat membuat siswa berpikir logis, kritis dan sistematis. Pendekatan analitik adalah suatu pendekatan yang mengharuskan siswa menganalisis dan meinterpresentasikan suatu model matematika dengan bimbingan yang terstruktur. Sedangkan pendekatan konstruktif adalah suatu pendekatan yang meminta siswa untuk bertanya pertanyaanpertanyaan kunci untuk mendapatkan gagasan yang mengarah ke ide untuk membuat model matematika. Pendekatan analitik dilakukan dengan meminta siswa untuk menganalisis dan menginterpretasikan suatu model matematika yang sudah ada. Sedangkan, pendekatan konstruktif dilakukan dengan memberikan pernyataan-pernyataan kunci yang mengarahkan siswa untuk membuat model matematikanya sendiri. 


\section{METODE PENELITIAN}

Penelitian ini menggunakan metode deskriptif kualitatifyang juga merupakan pengembangan dari artikelToshikazu Ikeda,Yokohama National University, Japan (2003). Tujuan dari penelitian ini adalah untuk membandingkan antara pendekatan analitik dan konstruktif dalam aktivitas pemodelan suatu masalah matematika serta melihat pendekatan mana yang dapat membuat siswa berpikir logis, kritis dan sistematis.

A. Rancangan Penelitian

Masing-masing kelompok kemudian diberi 3 masalah matematika yang diselesaikan dengan membuat model matematikanya terlebih dahulu. Penelitian ini dilakukan dalam satu kali pertemuan untuk setiap kelompoknya. Kelompok pertama menyelesaikan masalah tersebut dengan menggunakan pendekatan analitik sedangkan kelompok kedua menggunakan pendekatan konstruktif.

Peneliti mengamati, mendokumentasikan dan mencatat hal-hal penting terkait aktivitas siswa selama proses menyelesaikan masalah matematika tersebut. Selanjutnya, peneliti menganalisis hasil yang diperoleh yang berupa foto, hasil pengamatan, dan pekerjaan siswa untuk melihat alur berpikir kelompok dalam menyelesaikan masalah pemodelan tersebut.

B. Bahan Penelitian

1. Lembar Kerja Kelompok 1 (Pendekatan Analitik)

2. Lembar Kerja Kelompok 2 (Pendekatan Konstrutif)

3. Kertas HVS

4. Alat Tulis

5. Kamera

C. Subjek Penelitian

Subyek dari penelitian ini yaitu 7 orang siswa kelas XI yaitu Marwa, Robert, Cerry, Enta, Akbar, Namira, Andre. Siswa-siswa tersebut kemudian dibagi menjadi dua kelompok. Kelompok pertama beranggotakan 3 siswa yaitu Namira, Cerry, Enta dan kelompok kedua beranggotakan 4 siswa yaitu Marwa, Robert, Akbar, Andre.

D. Prosedur Penelitian

1. Menyiapkan soal

2. Merancang soal dengan pendekatan analitik

3. Merancang soal dengan pendekatan konstruktif

4. Mencari subjek penelitian

5. Membagi subjek penelitian menjadi dua kelompok

6. Memberikan soal pendekatan analitik kepada kelompok 1

7. Memberikan soal pendekatan konstruktif kepada kelompok 2

8. Mengamati, mendokumentasikan dan mencatat hal-hal selama proses penyelesaian kelompok 1

9. Mengamati, mendokumentasikan dan mencatat hal-hal selama proses penyelesaian kelompok 2

10. Menganalisis hasil kerja siswa

11. Membuat kesimpulan dari hasil penelitian

E. Instumen Penelitian

Soal tes diberikan untuk masing-masing kelompok. Kelompok pertama dengan pendekatan Analitik, yaitu:

1. Gita mempunyai 10 kelereng lebih sedikit dari Paijo.

Gita mempunyai 5 kelereng lebih banyak dari Meli. 
Paijo memberikan 4 kelereng kepada Meli.

Gita memberikan 6 kelereng lain kepada Meli.

Meli sekarang mempunyai 13 kelereng.

\section{Pertanyaan :}

a) Berapa kelereng yang dimiliki oleh Meli sekarang ?

b) Berapa kelereng yang dimiliki oleh Meli sebelum diberi oleh Gita ?

c) Berapa kelereng yang dimiliki oleh Meli sebelum diberi oleh Gita dan Paijo ?

d) Berapa kelereng yang dimiliki oleh Meli pada awalnya ?

e) Berapa kelereng yang dimiliki oleh masing-masing anak pada awalnya? Berikan penjelasannya!

2. Umur rata-rata dari suatu kelompok yang terdiri dari Dokter dan Jaksa adalah 40 tahun. Jika umur rata-rata para Dokter adalah 35 tahun dan rata-rata umur Jaksa adalah 50 tahun.

\section{Pertanyaan :}

a) Apa rumus umum untuk menentukan rata-rata umur Dokter, Jaksa maupun Dokter dan Jaksa?

b) Jika diketahui rata-rata Dokter atau Jaksa, bagaimana cara menentukan jumlah umur Dokter maupun jumlah umur Jaksa?

c) Bagaimana model yang digunakan untuk menentukan rata-rata umur Dokter dan Jaksa jika diketahui informasi sebelumnya?

d) Berapa perbandingan banyak Dokter dan Jaksa ? Berikan penjelasanya!

3. Tahun yang lalu gaji permulaan lima orang karyawan dalam ribuan rupiah sebagai berikut: Rp 480.000, Rp 360.000, Rp 650.000, Rp 700.000, dan Rp 260.000. Tahun ini gaji mereka naik $15 \%$ bagi yang sebelumnya bergaji kurang dari Rp 500.000,00 dan 10\% bagi mereka yang sebelumnya bergaji lebih dari Rp 500.000,00

\section{Pertanyaan:}

a) Berapa jumlah gaji pegawai yang gajinya dibawah $\mathrm{Rp} 500.000$ ?

b) Berapa kenaikan gaji pegawai yang gajinya diatas Rp 500.000 ?

c) Berapa jumlah gaji pegawai yang gajinya diatas Rp 500.000?

d) Berapa kenaikan gaji pegawai yang gajinya diatas Rp 500.000?

e) Apa rumus umum untuk mencari rata-rata?

f) Berapa rata-rata besarnya kenaikan gaji pegawai? Berikan penjelasannya!

Kelompok kedua dengan pendekatan konstruktif, yaitu:

1. Gita mempunyai 10 kelereng lebih sedikit dari Paijo.

Gita mempunyai 5 kelereng lebih banyak dari Meli.

Paijo memberikan 4 kelereng kepadaMeli.

Gita memberikan 6 kelereng lain kepada Meli.

Meli sekarang mempunyai 13 kelereng.

Pertanyaan :

Berapa kelereng yang dimiliki oleh masing-masing anak pada awalnya ?

2. Umur rata-rata dari suatu kelompok yang terdiri dari Dokter dan Jaksa adalah 40 tahun. Jika umur rata-rata para Dokter adalah 35 tahun dan rata-rata umur Jaksa adalah 50 tahun.

\section{Pertanyaan :}


Berapakah perbandingan banyak Dokter dan Jaksa?

3. Tahun yang lalu gaji permulaan lima orang karyawan dalam ribuan rupiah sebagai berikut: 480, 360, 650, 700, dan 260. Tahun ini gaji mereka naik $15 \%$ bagi yang sebelumnya bergaji kurang dari Rp 500.000,00 dan 10\% bagi mereka yang sebelumnya bergaji lebih dari Rp 500.000,00

\section{Pertanyaan:}

Hitunglah nilai rata-rata besarnya kenaikan gaji mereka !

\section{F. Teknik Penelitian}

Teknik pengumpulan data dilakukan dengan observasi, dokumentasi berupa foto, dan hasil pekerjaan kelompok. Observasi terhadap subjek dibagi menjadi dua tahap yaitu sebelum dan selama penelitian selanjutnya mencatat hal-hal penting yang terjadi. Selanjutnya observasi lakukan terhadap hasil pekerjaan masing-masing kelompok. Selama proses penelitian atau selama masing-masing kelompok menyelesaikan soal yang diberikan, peneliti mendokumentasikan proses tersebut dalam bentuk foto.

\section{HASIL DAN PEMBAHASAN \\ Proses dan Hasil Penelitian}

Penelitian dilaksanakan pada Oktober 2016. Bentuk data yang diperoleh adalah hasil pekerjaan siswa, foto dan transkrip hal-hal penting terkait aktivitas siswa selama proses pengerjaan. Penelitian dilakukan dengan memberikan tiga masalah matematika untuk diselesaikan dengan membuat model matematikanya terlebih dahulu kepada setiap kelompok siswa dengan dua pendekatan yang berbeda. Kelompok pertama dengan pendekatan analitik sedangkan kelompok kedua menggunakan pendekatan konstruktif. Peneliti mengamati dan mencatat hal-hal penting terkait aktivitas siswa selama proses pengerjaan. Selanjutnya semua pekerjaan siswa dilihat dan dikoreksi oleh peneliti.

Berikut merupakan hasil kerja kelompok 1 yang menggunakan pendekatan analitik:

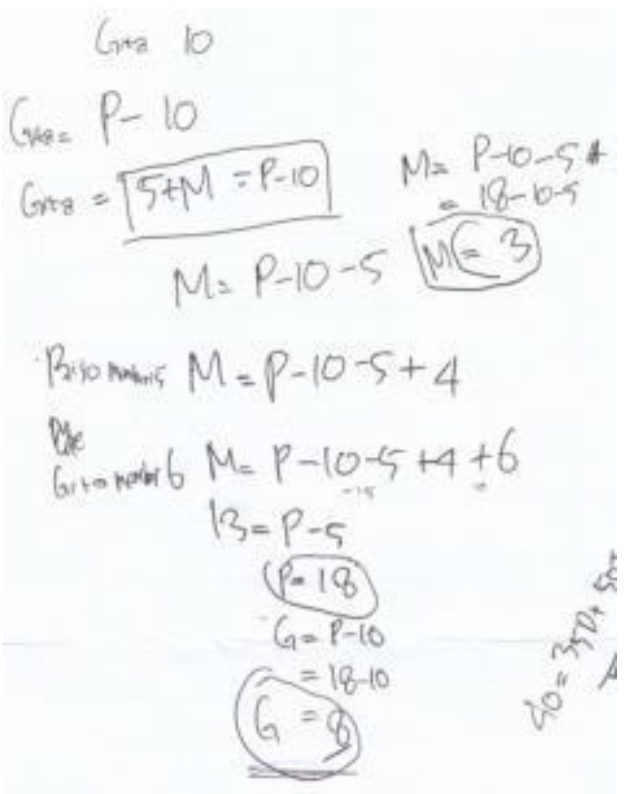

Gambar 1

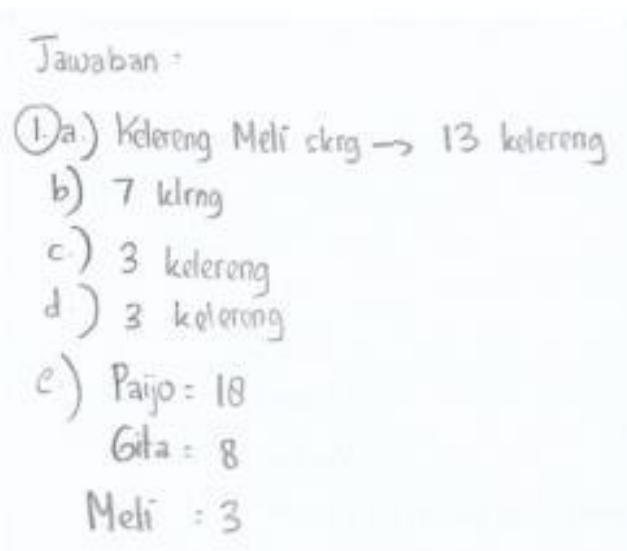

Gambar 2 
Pada soal nomer 1, kelompok menjawab dengan membuat pemodelan seperti gambar 1 . Kelompok menyelesaikan soal dengan cara berdiskusi dan membuat pemodelannya terlebih dahulu selanjutnya baru menyelesaikan permasalahan dengan menjawab pertanyaanpertanyaan penuntun untuk sampai ke pertanyaan utama atau pertanyaan terakhir.

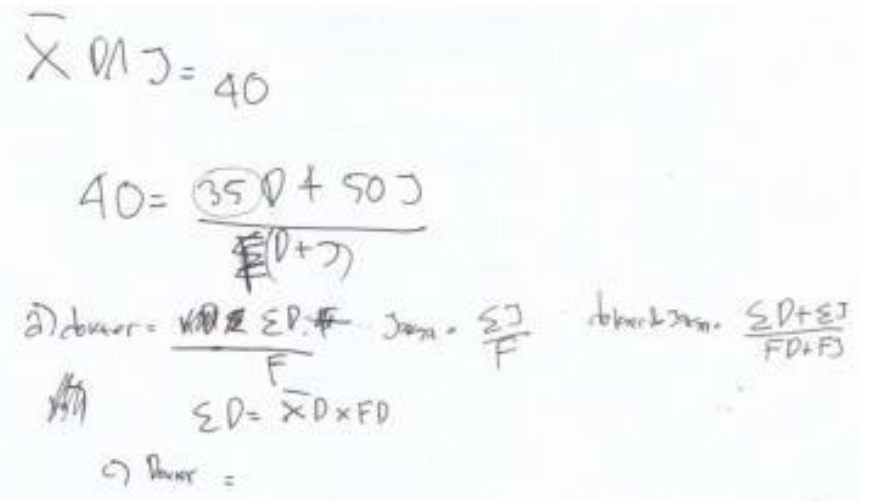

Gambar 3

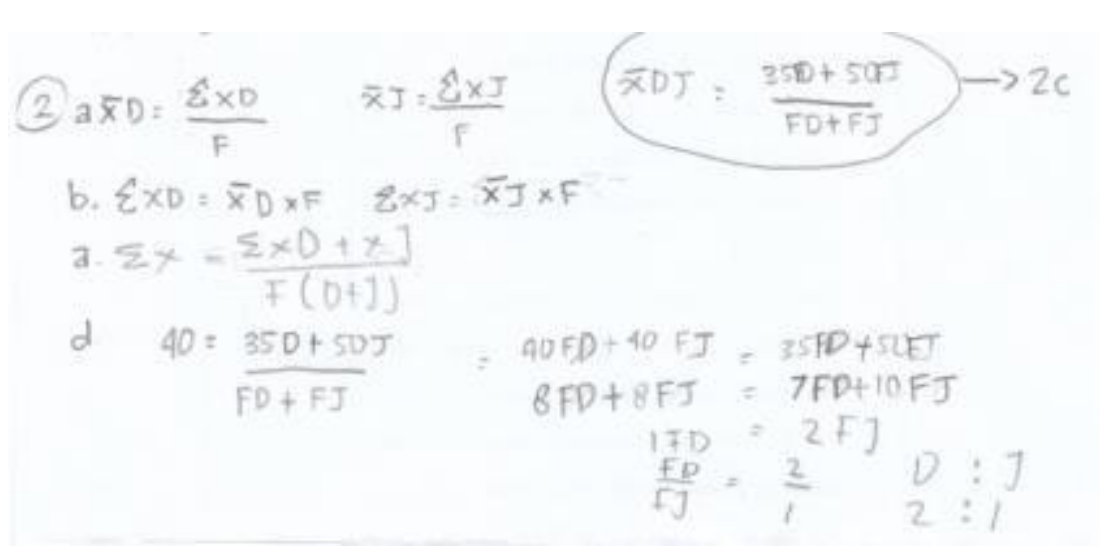

Gambar 4

Gambar 3 merupakan hasil proses diskusi sedangkan gambar 4 merupakan hasil akhir dari soal nomer 2. Pada proses penyelesaiannya, siswa kurang teliti dalam menuliskan simbol untuk jumlah umur dokter dan jumlah umur siswa. Kelompok baru menyadarinya saat mengikuti langkah selanjutnya kemudian memperbaiki jawabannya pada hasil akhir. Kelompok juga banyak mengajukan pertanyaan terkait cara penyelesaian dari soal ini. 


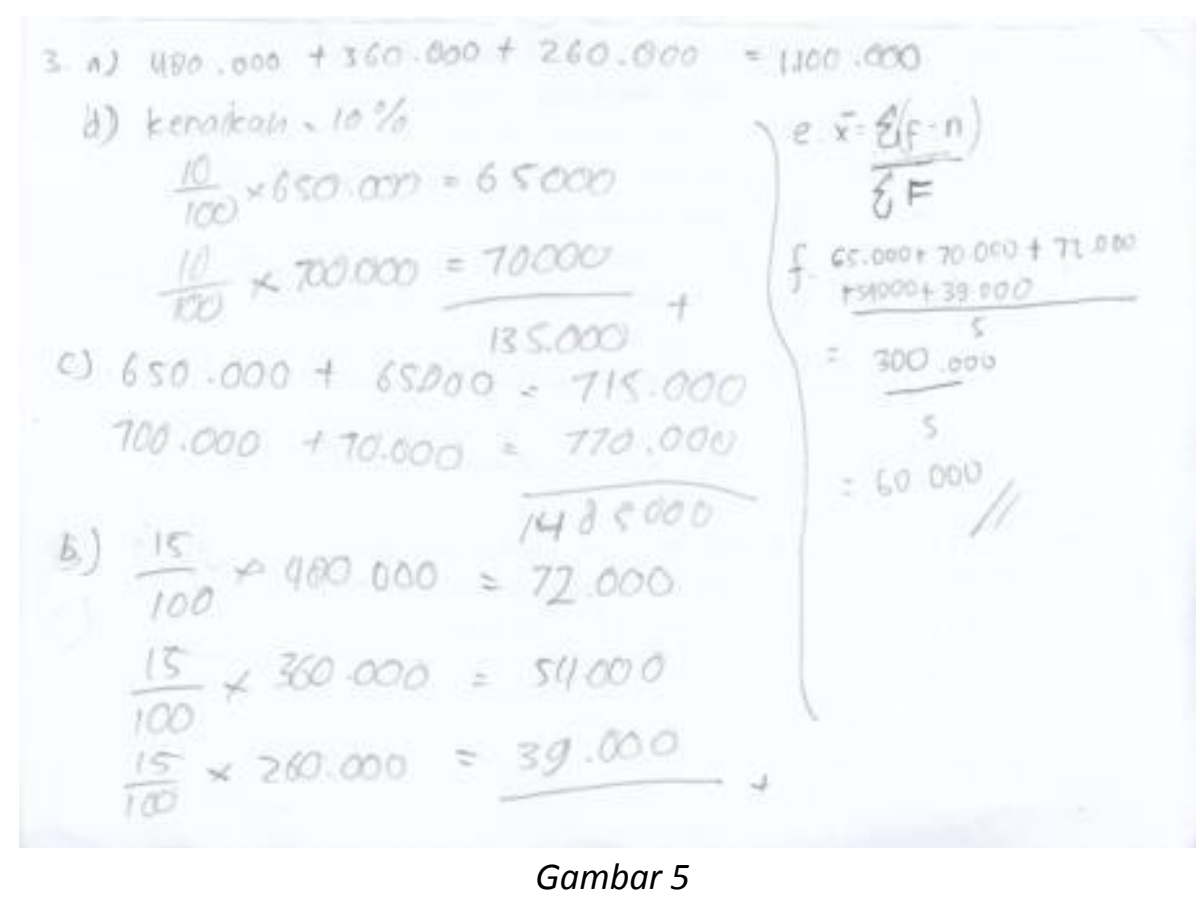

Gambar 5 merupakan hasil akhir dari soal nomer 3. Kelompok langsung menuliskan hasil akhir tanpa menggunakan kertas lain untuk proses diskusi. Selama proses penyelesaiannya, kelompok memulai dengan membaca soal dan langsung menjawab pernyelesaian dengan bertanya kepada anggota kelompoknya. Kolompok juga terlihat dapat menyelesaikan soal ini dengan lebih sedikit pertanyaan yang muncul.

Berdasarkan hasil penelitian terhadap kelompok yang menggunakan pendekatan analitik, peneliti mengetahui bahwa:

1. Kelompok masih banyak bertanya tentang maksud soal.

2. Kelompok bekerja dengan banyak bimbingan dari peneliti.

3. Kelompok terkadang masih bingung untuk membawa kedalam bentuk umum.

4. Kelompok aktif untuk berdiskusi dalam menentukan penyelesaian setiap soal dengan langkah-langkah yang diberikan.

5. Menyelesaikan soal secara lebih terurut sesuai langkah-langkah. 
Hasil pekerjaan kelompok 2 dengan menggunakan pendekatan Konstruktif:

Soal nomer 1

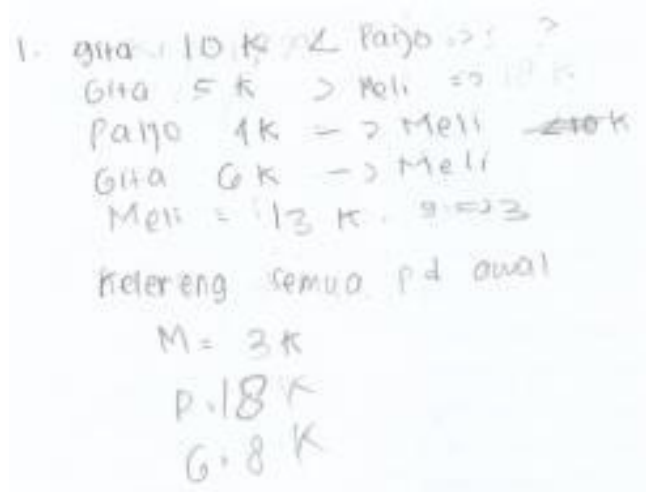

Gambar 6

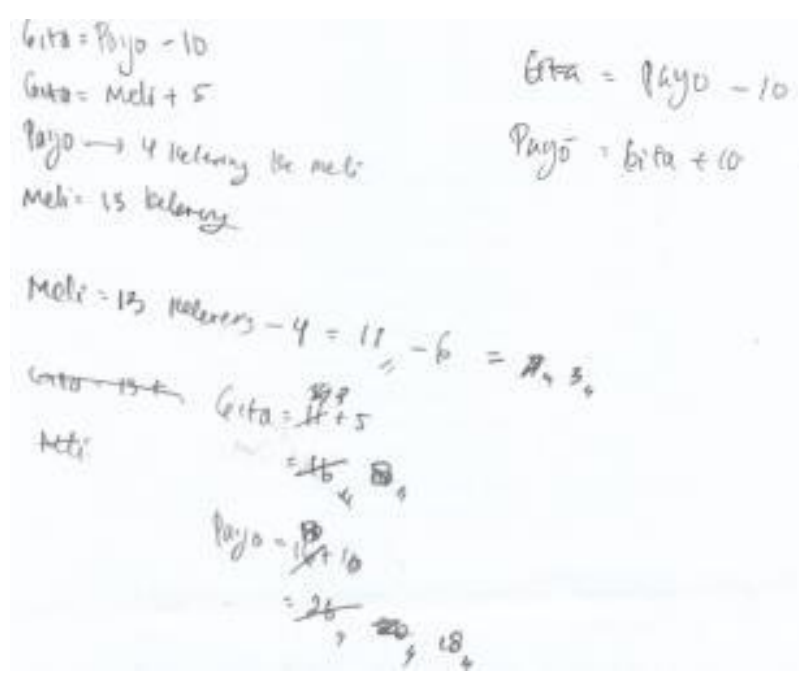

Gambar 7

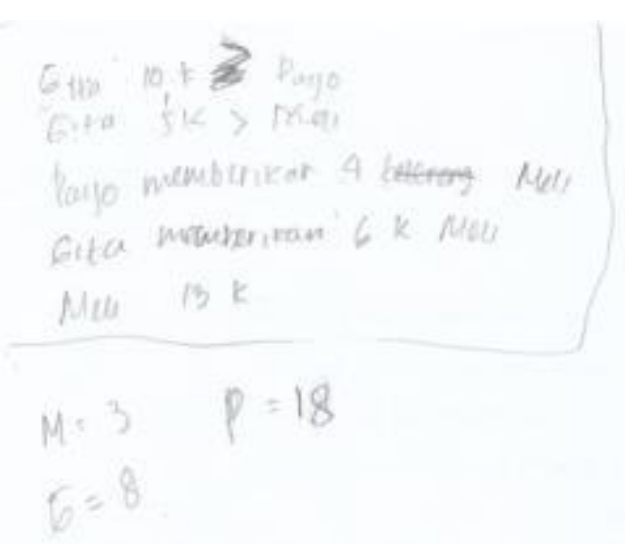

Gambar 8

Gambar 6, gambar 7, dan gambar 8 merupakan hasil penyelesaian yang dikerjakan oleh kelompok 2. Kelompok ini menyelesaikan soal nomer 1 sesuai pemahamannya masingmasing dan setiap anggota kelompok diberi kebebasan untuk menginterpretasikan melalui pemodelan yang dibuat menurut pemahamannya setelah membaca soal. Setelah menemukan hasil akhirnya, anggota kelompok cenderung bertanya kepada anggota yang lain untuk mencocokan jawabanya. 
Soal nomer 2

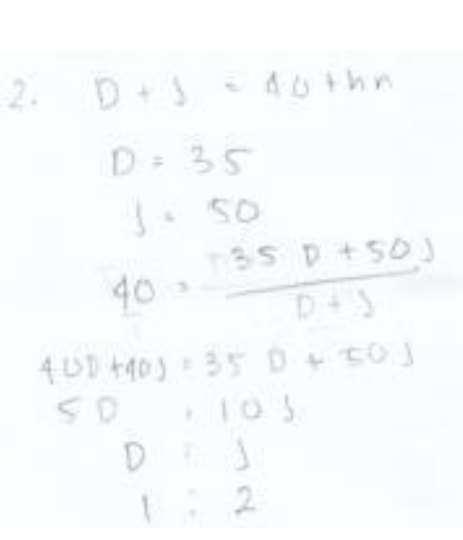

Gambar 9

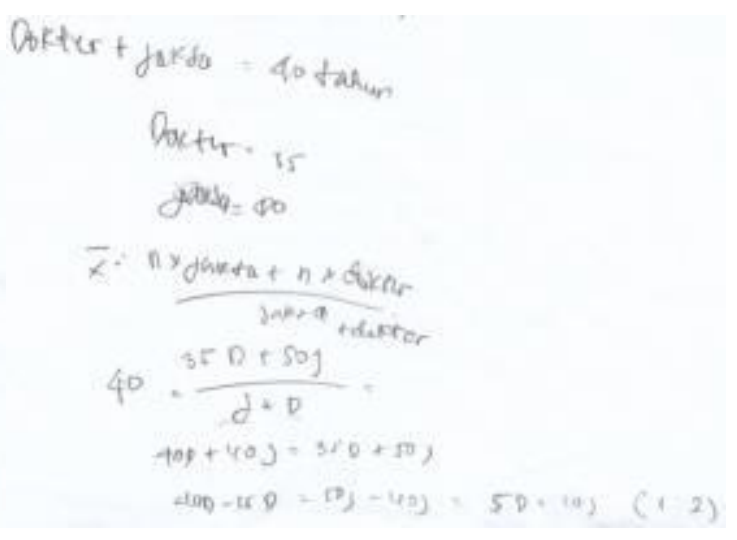

Gambar 10

Gambar 9 dan gambar 10 menunjukkan proses penyelesaian soal nomer 2 yang dikerjakan oleh kelompok.kedua penyelesaian tersebut secara umum dapat dikatakan hampir sama dengan perbedaan yang terletak pada penulisan simbol dalam pemodelannya.

Soal nomer 3

Gambar 11 


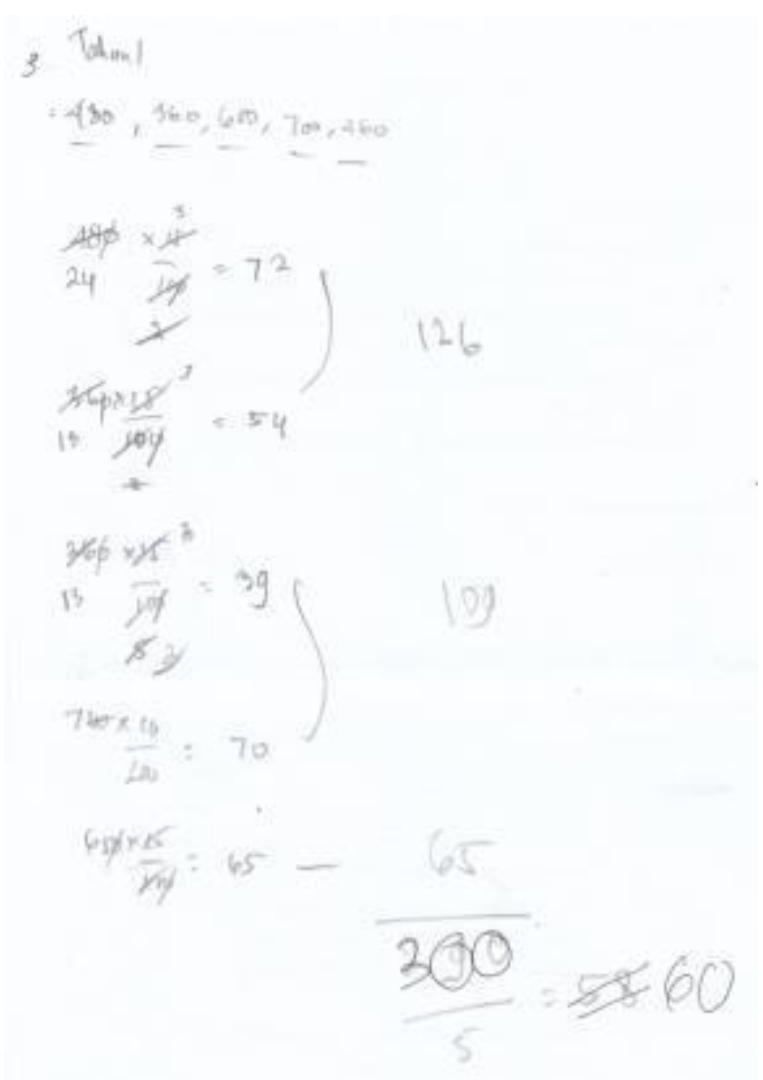

Gambar 12

Gambar 11 dan gambar 12 merupakan proses penyelesaian soal nomer 3 yangdilakukan oleh kelompok. Kelompok menyelesaikannya dengan sedikit bertanya kepada peneliti berkaitan dengan maksud soal, awalnya ada jawaban anggota kelompok yang kurang tepat setelah bertanya kepada anggota yang lain. Namun, setelah membaca soal berulang kali, anggota kelompok tersebut mengkoreksi hasil penyelesaiannya dan mengetahui letak kesalahannya.

Dari hasil pengamatan dan hasil kerja kelompok 2 yaitu kelompok yang menggunakan pendekatan konstruktif, peneliti mengetahui bahwa:

1. Siswa menyelesaikan soal secara bebas dengan hanya sedikit pertanyaan yang diajukan kepada peneliti.

2. Siswa dalam kelompok bekerja secara individual dan lebih mengekspresikan ideidenya sendiri untuk menyelesaikan soal.

3. Membaca soal lebih teliti untuk mencari informasi yang diberikan.

4. Setelah mendapatkan penyelesaian setiap soal, siswa bertanya kepada teman kelompoknya tentang jawabannya apakah sudah sama atau ada perbedaan kemudian mendiskusikannya.

5. Siswa membaca soal secara berulang-ulang dan memastikan jawabannya. 


\section{KESIMPULAN}

Aktivitas pemodelan dengan menggunakan pendekatan analitik terlihat logis dan sistematis karena pertanyaan-pertanyaan yang disusun sedemikian sehingga siswa dapat menemukan penyelesaian dari masalah utama yang diberikan, namun kurang kritis karena selama proses pengerjaan siswa terlalu banyak bertanya dan menunggu arahan dan tidak memeriksa kembali hasil pekerjaannya. Sedangkan, aktivitas pemodelan dengan pendekatan konstruktif terlihat cukup logis dan kritis, siswa menyelesaikan masalah dengan memperhatikan pernyataan-pernyataan yang diberikan. Namun terkadang kurang sistematis karena selama proses pengerjaan siswa menyelesaikan masalah tersebut dengan cara mereka sendiri sesuai informasi yang mereka pahami. Setelah soal selesai, siswa bertanya apakah hasil mereka sudah benar dan memeriksanya kembali.

\section{DAFTAR PUSTAKA}

Huston, SJ Lamon, W A Parker, dan S K. (2003). Mathematical Modelling : A Way Of Life. Horwood Publishing Chicchester : England.

Enung, S. dan Untung, W. (2009). Matematika untuk SMA/MA Kelas XI Program Ilmu Alam. Penerbit Erlangga : Jakarta.

Alsa, K. (2014). Macam-macam Pendekatan Pembelajaran. Diakses pada tanggal 15 September 2016. Tersedia: http://rizkyamaliahalsa.blogspot.co.id/2014/06/macammacam-pendekatan-pembelajaran.html.

Suparno, P. (2001). Filsafat Konstruktivisme dalam Pendidikan. Yogyakarta : Kanisius. 